\title{
The Right To Petition In THE REPUblic OF Poland - New Challenges and NeW Solutions
}

\author{
EWA WÓJCICKA*
}

\section{INTRODUCTION}

The aim of this work is to present and analyse the legal views of the right to petition specified expressly in Article 63 of the Basic Law. In the first instance this article concentrates on the review of petitioning genesis in Europe and the functions of this right. Then, I am going to discuss the process of restoration of the institution of petitioning in the Polish legal system, the prevailing conceptions of the right to petition, and then the subjective and objective scope of the right of petition. The article also tries to answer the question of whether the present normative shape of the right of petition is understood correctly, and if not, which reforms should be introduced to adjust it to the standards and requirements of the democratic state.

\section{THE IDEA, ORIGINS AND THE GROWTH OF THE RIGHT TO PETITION}

The right to petition is one of the basic rights in all democratic systems. The term petition derives from the Latin word petitio, which means "attack" or "plead". ${ }^{1}$ The history of petitioning in Europe is linked to the history of the constitutional development of England, where the first mention of redress appeared. ${ }^{2}$ Originally, petition was a request to compensate for grievances, sent by a subject to a ruler. It was characterized by a humble tone and it recognized the higher status of an addressee. ${ }^{3}$ A traditional petition

DOI: $10.1515 /$ wrlae-2018-0009

* PhD, Assistant Professor, Institute of Law, Administration and Management, Jan Długosz University, Częstochowa. Email: e.wojcicka@ajd.czest.pl

${ }^{1}$ Aleksander Brückner, Słownik etymologiczny języka polskiego [Etymological Dictionary of the Polish Language] (Wiedza Powszechna 1970) 403; Tor Hauken, Petition and Response. An Epigraphic Study of Petitions to Roman Emperors 181-249 (The Norwegian Institute at Athens 1998) 259-264.

${ }^{2}$ David J Bodenhamer, Our Rights (Oxford University Press 2007) 90.

${ }^{3}$ David Zaret, 'Petitions and the 'Invention' of Public Opinion in the English Revolution' (1996) 6 American Journal of Sociology 1512-1515. 
included humble requests to a ruler, not people's demands. ${ }^{4}$ Petition submitting constitutes a historical and fundamental right of every subject, as well as a parliamentary tradition. Its uninterrupted development has been marked by a quite astonishing continuity. In the Middle Ages it became the most common and accessible means of pursuing individual rights and interests. The concept of presenting pleas and grievances evolved rapidly in the successive centuries (especially the seventeenth and eighteenth) influencing not only the protection of personal rights of individuals, but also the shaping of political awareness among citizens. ${ }^{5}$ As G. Lawson and G. Seidman noted "the right to petition boasts a distinguished pedigree, running from Magna Carta in 1215, through royal commitments in the Petition of Rights of 1628 and the Bill of Rights of 1689 to seventeenth- and eighteenthcentury parliamentary guarantees of a general right to petition". ${ }^{6}$ The "Golden Age" of this institution was the early modern period and the development of democracy and the parliamentary system. Then, the petition changed into the device which not only served to express requests and complaints of an individual, but it was also used to influence legislation. ${ }^{7}$ Ipso facto, the petition became a significant instrument of legislative initiative and a device shaping public opinion and encouraging the citizens to participate in the affairs of State.

A milestone in the history of petition was the publication of Bill of Rights in 1689 and a clear ruler's statement concerning the binding force of this law. Since then, we can talk about the right to petition in modern meaning of this word. ${ }^{8}$ English solutions strongly influenced the constitutionalism of democratic countries. As a result of the adoption of the first constitutions, the status of an individual in the country changed fundamentally and petitioning received a constitutional guarantee. This process grew stronger in the $19^{\text {th }}$ century. Following the example of the English solutions, other countries also recognised petitioning as a common right of their subjects, which could be used without the fear of suffering.

Today, in a number of states the right to petition is a constitutional right. The right to petition is the most widespread in Europe $^{9}-$ it is present in

\footnotetext{
${ }^{4}$ David Zaret, Origins of Democratic Culture: Printing, Petitions and the Public Sphere in Early Modern England (Princeton University Press 2000) 15; Susan Zaeske, Signatures of Citizenship: Petitioning, Antislavery, and Women's Political Identity (Chapel Hill 2003) 34.

${ }^{5}$ Ewa Wójcicka (translated by M. Bąk), 'Prawo petycji do Parlamentu Wielkiej Brytanii. Geneza i rozwój' [The Right to Petition the Parliament of Great Britain: Genesis and Development] (2010) 4 Studia Erasmiana Wratislaviensia 208.

${ }^{6}$ Gary Lawson, Guy Seidman, 'Downsizing the Right to Petition' (1999) 3 Northwestern University Law Review 740.

${ }^{7}$ See: Beat Kümin, Andreas Würgler, 'Petitions, Gravamina and the Early Modern State: Local Influence on Central Legislation in England and Germany' (1997) 17 Parliaments, Estates \& Representation 39-60; Norman B Smith, "“Shall Make No Law Abridging ...": An Analysis of the Neglected, But Nearly Absolute, Right of Petition' (1986) 54 University of Cincinnati Law Review 1154.

${ }^{8}$ Jacek Lang, Wnioski obywatelskie $w$ administracji państwowej [Citizens' proposals in the state administration] (Wydawnictwa UW 1976) 176.

${ }^{9}$ Constitutions: 1) Albania 1998 (art. 48), 2) Austria 1920 (art. 148a), 3) 17. Belgium 1831 (art. 28), 4) Belarus 1994 (art. 40), 5) Bulgaria 1991 (art. 45), 6) Croatia 1990 (art. 46), 7) Charter of Fundamental Rights and Freedoms of the Czech Republic 1992 (art. 18), 8) Estonia 1992 (art. 46), 9), France, 1958 (art. 72-1), 10) Greece 1975 (art. 10), 11), Spain 1978 (art. 29), 12) Netherlands 1814 (art. 5), 13) Lithuania 1992 (art. 33), 14) Latvia 1922 (art.
} 
the constitutions of 34 countries and in Russia (Art. 33). It is interesting that petitioning is also present in relatively high number of countries in South and North America ${ }^{10}$. The right to petition has a smaller range of its validity in Asia $^{11}$ and Africa ${ }^{12}$. Petitioning is also guaranteed in the constitutions of countries and independent territories from the region of Australia and Oceania (Tonga, Palau, the Marshall Islands, American Samoa). ${ }^{13}$ As W. Sadurski ${ }^{14}$ rightly pointed out the right to petition is formulated in a number of different ways. At one end of the scale is the right to simply be able to lodge a petition. Other constitutions then expand this to include the right to receive an answer within a statutorily specified period of time. ${ }^{15}$ Other constitutions guarantee the right to not suffer negative repercussions from having put forward a petition (Japan, Spain, Macedonia, Switzerland, Serbia, Montenegro, Costa Rica $\left.^{16}\right)$. Consequently, it is difficult to give a general definition of the right to petition. Depending on national traditions, the petition may incorporate a suggestion, an initiative or express complaints.

Petitions play an important role in the "contemporary democratic process". ${ }^{17}$ Petitions are a form of semi-direct democracy, which combines

104), 15), Luxembourg 1868 (art. 27), 16), Macedonia 1991 (art. 24), 17) Moldova 1994 (art. 52), 18) Monaco 1962 (art. 31), 19), Germany 1949 (art. 17), 20) Poland 1997 (art. 63), 21), Portugal 1976 (art. 52), 22) Romania 1991 (art. 51), 23) Slovakia 1991 (art. 27), 24) Slovenia 1991 (art. 45), 25), Switzerland, 1999 (art. 33), 26) Turkey 1982 (art. 74), 27) Ukraine 1996 (art. 40), 28) Hungary 2011 (Art. XXV), 29) Italy 1947 (art. 50), 30) Montenegro 2007 (art. 57), 31) Serbia 2006 (art. 56), 32) Liechtenstein 1921 (art. 42); 33) Andorra 1993 (art. 23); 34) Denmark 1953 (\$ 54).

${ }^{10}$ Constitutions: 1) Argentina 1994 (art. 14), 2) Bolivia 2009 (art. 24), 3) Brazil 1988 (art. XXXIV p. A), 4) Chile 1980 (art. 19), 5) Ecuador 2008 (art. 66 p. 23), 6) Guatemala in 1985 (art. 28), 7) Haiti 1987 (art. 29), 8), Honduras 1982 (art. 80), 9), Colombia 1991 (art. 23), 10) Costa Rica 1949 (art. 27), 11) Cuba 1992 (art. 63), 12) Mexico 1917 (art. 8), 13) Nicaragua 1987 (art. 52), 14) Panama 1972 (art. 41), 15) Paraguay 1992 (art. 40), 16) Peru 1993 (art. 2s), 17) El Salvador 1983 (art. 18), 18) Suriname 1987 (art. 22), 19) Uruguay 1967 (art. 30), 20) Venezuela 1999 (art. 31), 21) United States of America 1789 (I amendment).

${ }^{11}$ Constitutions: 1) Azerbaijan 1995 (art. 57), 2) China 2004 (art. 41), 3) Cyprus 1960 (art. 29), 4) Japan 1946 (art. 16), 5), Korea 1948 (art. 26), 6) Kuwait 1962 (art. 45), 7), Laos 1991 (art. 28), 8) Mongolia 1992 (art. 16), 9) Oman 1996 (art. 34), 10) Tajikistan 1994 (art. 31), 11) Thailand 2007 (art. 59), 12) Timor-Leste 2002 (art. 48), 13) Philippines 1987 (the Bill of Rights, art. III, sec. 4), 14) Vietnam 1992 (art. 53), 15) Jordan 1952 (art. 17), 16) Uzbekistan 1992 (art. 35), 17) Yemen 1994 (art. 50), 18) Bahrain 2002 (art. 29), 19) India 1949 (art. $350)$.

12 Constitutions: 1) Burkina Faso 1991 (art. 30), 2) Ethiopia 1994 (art. 30), 3) Equatorial Guinea 1991 (art. 13 p. h), 4), Democratic Republic of the Congo 1992 (art. 18), 5), Mozambique 1990 (art. 80), 6) Republic of the South Africa 1996 (art. 17), 7) Uganda 1996 (art. 29, d), 8) Cape Verde 1992 (art. 57), 9), Gambia 1997 (art. 25) 10) Liberia 1984 (art. 17), 11. Morocco 2011 (art. 15).

${ }^{13}$ Ewa Wójcicka, 'Petycja w prawie konstytucyjnym państw współczesnych' [Petition in the Constitutional Law of Modern States] (2008) 1 Ius Novum 25.

14 Wojciech Sadurski, Rights Before Courts: A Study of Constitutional Courts in Postcommunist States of Central and Eastern Europe (Springer 2014) 219.

15 Right to receive an answer includes constitutions of: Azerbaijan, Belarus, Costa Rica, Croatia, Montenegro, Serbia, Cyprus, Cuba, Korea, Ecuador, El Salvador, Honduras, Nicaragua, Panama, Paraguay, Portugal, Romania, Greece, Macedonia, Mexico, Mongolia, Thailand, Turkey and Ukraine.

${ }^{16}$ For example Article 24 of the constitution of Macedonia says: "citizen cannot be called to account or suffer adverse consequences for attitudes expressed in petitions, unless they entail the committing of a criminal offence".

${ }^{17}$ Ruth Fox, 'Engagement and participation: What the public want and how our politicians need to respond' (2009) 62 Parliamentary Affairs 683. 
the features characteristic for direct democracy as well as representative one. $\mathrm{S}$. Watt describes petitioning as "a manifestation of informal politics, a practice initiated by ordinary citizens which aim to influence the deliberations of political authorities". ${ }^{18}$ The right to petition fulfils three main functions which decide about the need of its existence within the representative system. These are: the political function, the control function and the function of extralegal means of man's rights and the protection of freedom. Petitions are an instrument for protecting citizens' rights and public interests; they are also a very special form of citizen participation. One should emphasise the importance of petitioning as a way for individuals to be formally heard and their concerns considered within the institutions". Petitions represent an element of the participatory process in which citizens can place their own topics on the political agenda and are a particularly nonbureaucratic participatory instrument. This gives them a fundamentally political character. ${ }^{19}$ A. Vromen and K. Gelber contend that "petitions are a mechanism that allows members of the public to communicate directly with the parliament, to tell the parliament of a particular problem and to seek a parliamentary action to remedy it". They tend to be concerned with current political issues, and their aim is to persuade parliamentarians that they should pay attention to the particular views contained within them. ${ }^{20}$ Petitioning is a key tool for participation and democratic control by citizens. The right to petition enhances the authority towards the citizens, while at the same time providing individuals with an open, democratic and transparent mechanism for obtaining, where legitimate and justified, a non-judicial remedy for their complaints. $^{21}$

\section{The Right to Petition IN Polish LAW}

The right to petition is recognized not only by the constitutions of countries with rich democratic traditions, but also by those, which after many years of totalitarianism undertook the building of new political systems after the year 1989. Poland belongs to this second group of countries, although the institution of petitioning has a long tradition and it was known even at the beginning of the $15^{\text {th }}$ century. As in England, the development of this institution was connected to the presentation of the demands to the king. Their fulfilment was a condition on which the gentry agreed to higher taxes. ${ }^{22} \mathrm{By}$

\footnotetext{
${ }^{18}$ Niamh Corbett, 'Parliamentary petitions: An untapped library resource [online]' (2011) 3 Australian Library Journal 219.

${ }^{19}$ Ulrich Riehm, Knud Böhle, Ralf Lindner, Electronic petitioning and modernization of petitioning systems in Europe (Büro für Technikfolgen-Abschätzung beim Deutschen Bundestag 2014) 34.

${ }^{20}$ Corbett (n 18) 220.

${ }^{21}$ European Parliament resolution of 11 March 2014 on the activities of the Committee on Petitions 2013

${ }^{22}$ Wojciech Uruszczak, 'Sejm w latach 1506-1540' [Seym over the period 1506-1540] in Jerzy Michalski (ed), Historia sejmu polskiego, t. 1, Do schytku szlacheckiej Rzeczypospolitej [History of the Polish Seym, vol. 1: Toward the end of the Noble Republic of Poland] (Państwowe Wydawnictwo Naukowe 1984) 108-109; Anna Sucheni-Grabowska, 'Kilka uwag o miejscu króla w sejmach "złotego wieku"' [A Few Remarks on the Place of the King in the Seym in the "Golden Age"] in Krystian Matwijowski, Zbigniew Wójcik (eds), Studia z dziejów Rzeczypospolitej Szlacheckiej [Studies from the History of the Republic of the
} 
means of petitia, a real influence was exerted on nationwide matters, both in the internal and international politics. The further development of parliamentarianism caused petitia to become an instrument of Polish legislative initiative. Poland's partitions in the second half of the $18^{\text {th }}$ century put an end to state-run establishments and brought about huge changes in political life. Although the right to petition - in different times and scope was in force in all three countries which participated in the partition of Poland (Prussia, Russia and Austria), its realization by the Poles was largely limited. For example, the petitions were disregarded by the ruler, and the Polish language was discriminated against. Only the regaining of independence and the resolution of the Constitution of the Republic of Poland of 17th March 1921, restored due importance to the right to petition. ${ }^{23}$

Real socialism and the dictate of the Union of Soviet Socialist Republics (the USSR) questioned again the sense and need of the existence of this law. Every sign of social independence was removed. Institutions which survived the partition and the interwar period were liquidated. The communist authorities eliminated the notion of "petition" from legal regulations not only in Poland, but also in other satellite countries. Following the solutions included in the Constitution of the USSR, "complaints, proposals and grievances" were introduced instead of the right of petition, and the term "petition" was regarded as "bourgeois" and incitement to collective rebellion. ${ }^{24}$

After many years of the discontinued existence of the institution of petition in the Polish legal system, the Constitution of the Republic of Poland $^{25}$ restored it in 1997. Its new shape was a synthesis of five projects ${ }^{26}$ supporting the institution, variant projects of the Constitution, and the experts' reports and opinions, which were contributed to the final result of the Constitutional Commission's work. Several controversies arose in the discussion about the legal form of the petition. They were: who was entitled to take advantage of this new law, the criterion of the interest, which decided the usage, and also the problem of possible collision between the petition with the protection of privacy. In spite of the clear differences in their opinions, the Members of the Constitutional Commission of the National Assembly approved the final version of this law at the 39th session. The final version grants everyone the right to submit petitions, proposals and complaints in the public interest, in his own interest or in the interests of another person - with his consent - to organs of public authority, as well as to organizations and

Nobility] (Wydawnictwo Uniwersytetu Wrocławskiego 1988) 77; Stanisław Płaza, Anna Sucheni-Grabowska, 'Z badań nad polskim parlamentaryzmem XVI w.' [From the Research on Polish Parliamentarianism in the 16th century] (1974) 1 Czasopismo Prawno-Historyczne 63-75.

${ }^{23}$ According to art. 107 "Citizens have the right of presenting individual or collective petitions to all state and self-government representative bodies and public authorities".

${ }^{24}$ Ewa Wójcicka, Prawo petycji w Rzeczypospolitej Polskiej [The Right to Petition in the Republic of Poland] (Wydawnictwo Sejmowe 2015) 118-119.

25 The Constitution of the Republic of Poland of 2 April 1997, Journal of Laws No. 78, item 483.

${ }^{26}$ It was a project of: Constitutional Committee of the Senate (I Cadency); Parliamentary Club of Democratic Union; Democratic Left Alliance Parliamentary Club; project of the Polish President Lech Walesa; citizens' project. All projects were published in Ryszard Chruściak, Projekty konstytucji 1993-1997 [Drafts of the Constitutions 1993-1997] (Wydawnictwo Sejmowe 1997). 
social institutions in connection with the performance of their prescribed duties within the field of public administration. The procedures for considering petitions, proposals and complaints shall be specified by statute. The right to bring a petition, complaint or proposal to the state bodies, the local government bodies and social organisations and institutions are governed by the act of 11 July 2014 about the petitions ${ }^{27}$ and the act of 14 June 1960 Code of Administrative Procedure ${ }^{28}$.

\section{THE NORMATIVE SHAPE OF THE RIGHT TO PETITION}

In the light of Article 63 of the Constitution the right to petition is vested in "everyone". The aforementioned constitutional provision is contained in Chapter II of the Constitution (in the section "Political freedoms and rights"), governing rights, freedoms and duties of persons and citizens. Constitutional rights and freedoms are addressed to, above all, natural persons. The constitutional expression of this assumption is contained in Article 30, which provides that the dignity of the person constitutes the source of rights and freedoms and that these rights and freedoms have a primary character vis-à-vis law created by the State. The constitutional character of rights and freedoms, thus defined, is significant when establishing the normative contents thereof. This is also true in respect of the right to petition. Accordingly, the constitutional scheme indicates that the right to petition is considered as the right of an individual (citizens, adults, minors, people from other countries). As the wording of this provision clearly indicates, the right to petition does not depend on the one's personal circumstances, such as nationality. Petitions can be submitted both by individuals and also by groups of people. Petition may be lodged not only by a natural person. The right referred to in Article 63 shall also vest in - under certain conditions - a private legal person. Legal persons may be subjects of constitutional rights and freedoms to a limited degree. Certain of these rights and freedoms may not, by virtue of their substance, be vested in legal persons. As regards other constitutional subjective rights, a legal person may be the subject of such rights to the extent that this facilitates fuller enjoyment thereof by natural persons. In other words, vesting legal persons with constitutional rights has a derivative character in relation to the individuals' rights. The subject of the right to petition can be anyone and everyone, namely the private person as well as the legal person, regardless of their possible legal or actual interest. The discussed problem is different as regards the locus standi of public legal persons established on the basis of decisions adopted by the legislator or other State authorities and fulfilling tasks of a public legal nature. There is no similarity between the legal situation of legal persons performing public duties, particularly communes, and the legal situation of natural persons and private legal persons, such as would justify including the former within the scope of application of the constitutional right to petition. ${ }^{29}$

\footnotetext{
${ }^{27}$ Journal of Laws 2014, item 1195.

28 Journal of Laws 2017, item 1257.

${ }^{29}$ Decision of the Constitutional Tribunal of 23 February 2005, Case No. Ts 35/04, All decisions of the Constitutional Tribunal cited in this paper are available at < http://otk.trybunal.gov.pl/orzeczenia/>.
} 
Article 63 of the Constitution clearly indicates that the right to petition concerns petitions, proposals and complaints submitted to organs of public authority and to social organisations and institutions in connection with the performance of their prescribed duties within the field of public administration. The Constitutional Tribunal found that "the notion of a 'public authority' comprises all authorities in the constitutional sense, as well as other institutions - other than State or self-government organs - which have been entrusted by State or self-government organs to exercise powers on their behalf, or have had such powers conferred upon them by such organs". ${ }^{30}$ The right shall be exercised before any authority and with regard to any issue within their competence. A broad definition of a circle of the bodies of public authority creates a problem of receiving petitions, complaints and proposals by the bodies of judicial authority. Although courts comprise a classical tripartite division of power, it must be said that in relation to these subjects the exercise of the right to petition is considerably limited. A petition (proposal and complaint) must not interfere with the independence of a court. The right specified in Article 63 of the Constitution does not encompass initiating court proceedings. ${ }^{31}$

It is worth noting that an attribute of the right of petition is "liberty". The doctrine notes that, "on the one hand, the liberty relates to the external sphere of individual's activity (everyone may decide on their own conduct or behaviour, thus determining their own manner of influencing the outside world), and, on the other hand, to the sphere of personal safety and integrity (that sets the limits of the influence from the outside world on the individual)". 32 The doctrine and jurisdiction distinguished between positive and negative liberty. Negative liberty is the absence of obstacles, barriers or constraints. Positive liberty is the possibility of acting - or the fact of acting - in such a way as to achieve one's fundamental purposes. ${ }^{33}$ As the Constitutional Tribunal found in the positive aspect of liberty consists the fact that the individual may independently shape their behaviour in a given sphere, choosing between such forms of activity that suit them best, or may refrain from any activity whatsoever. The negative aspect of liberty consists in the legal obligation to refrain - by anyone - from any interference in the sphere reserved for the individual. ${ }^{34}$ This attribute of the right to petition imposes on a state a duty to create conditions favouring enjoyment of this right by an individual with simultaneous consideration of autonomy and freedom of choices made by him. This duty was included by the legislator in Art. 225

\footnotetext{
${ }^{30}$ Judgment of the Constitutional Tribunal of 4 December 2001, Case No. SK 18/00.

${ }^{31}$ Judgement of the Constitutional Tribunal of 16 November 2004, Case No. P 19/03.

32 Leszek Garlicki, 'Komentarz do art. 31 Konstytucji' [Commentary to art. 31 of the Constitution] in Leszek Garlicki (ed), Konstytucja Rzeczypospolitej Polskiej. Komentarz [Constitution of the Republic of Poland. Commentary] (Wydawnictwo Sejmowe 2003) 8.

${ }^{33}$ The idea of distinguishing between a negative and a positive sense of the term freedom was examined by Isaiah Berlin. In Berlin's words, we use the negative concept of liberty in attempting to answer the question "What is the area within which the subject - a person or group of persons - is or should be left to do or be what he is able to do or be, without interference by other persons?" Positive liberty is the answer to the question "What, or who, is the source of control or interference that can determine someone to do, or be, this rather than that?" Isaiah Berlin, Dwie koncepcje wolności [Two Concepts of Liberty] (Res Publica 1991) 114.

34 Judgement of the Constitutional Tribunal of 18 February 2004, Case No. P 21/02; Judgement of 7 March 2007, Case No. K 28/05.
} 
par. 2 of the act of 14 June 1960 Code of Administrative Procedure, constituting that "State bodies, local government bodies and social organisation bodies are required to act against restrictions on criticism and other actions that limit the right to submit complaints or proposals or provide information for publication that has the characteristics of a complaint or proposal".

\section{THE NEW SOLUTION - OLD PROBLEMS}

As has been pointed out before, the right to petition specified in Article 63 of the Constitution contains three measures: petitions, proposals and complaints. The subject of complaints and proposals is defined in Articles 227 and 241 act of 14 June 1960 Code of Administrative Procedure. The former says: Complaints may be directed against the negligent or inappropriate performance of duty by the proper body or its employees, breaches of the rule of law or the interests of the complainant, or the lengthy or bureaucratic processing of cases. Pursuant to Article 241 proposals can be made to improve organisation, to strengthen the rule of law, to streamline work and prevent abuses, to protect property and to meet the needs of the public better. The subject of the petition is defined in art. 2 par. 3 act of 11 July 2014 about the petitions: the subject of the petition might be a demand, particularly to change the law, make a decision or take action concerning the subject submitting the petition, public life or values which require a special protection in the name of common good, which comprise the tasks and powers of the petition addressee. Generally, the standpoints of the law representatives can be divided into three categories. According to the first standpoint, petition differs from complaints and proposals, and the differences between them are connected with the subject of these means $(\mathrm{H}$. Zięba-Załucka ${ }^{35}$, K. Działocha ${ }^{36}$ ), aim (P. Winczorek ${ }^{37}$ ) or the circle of addressees obliged to receive them (B. Banaszak ${ }^{38}$ ). The representatives of the second standpoint claim that the petition - depending on its subject should be treated similarly to a complaint or a proposal (M. Wierzbowski ${ }^{39}$, $\mathrm{J}$. Borkowski ${ }^{40}$ ). In contrast, the representatives of the third standpoint think that Article 63 of the Constitution establishes the right to petition which comprises three institutions: petitions sensu stricto (of collective character)

\footnotetext{
${ }^{35}$ Hanna Zięba-Załucka, 'Prawo petycji w Rzeczypospolitej Polskiej' [The Right to Petition in the Republic of Poland] (2010) 4 Przegląd Prawa Konstytucyjnego 18.

${ }^{36}$ Kazimierz Działocha, 'Prawo petycji w obowiązującym ustawodawstwie i proponowane kierunki zmian' [The Right to Petition in the existing legislation and the proposed directions of changes] in Prawo petycji w ustawodawstwie polskim [The right to petition in Polish legislation] (Kancelaria Senatu 2008) 2, 4.

37 Piotr Winczorek, Komentarz do Konstytucji Rzeczypospolitej Polskiej z dnia 2 kwietnia $1997 r$. [Commentary to the Constitution of the Republic of Poland of 2 April 1997] (K.E. Liber 2000) 86.

${ }^{38}$ Bogusław Banaszak, 'Opinia na temat projektu ustawy o petycjach' [Opinion on the draft Act about the petitions] in Opinie prawne na temat projektu ustawy o petycjach [Legal Opinions on the draft Act about the Petitions] (Kancelaria Senatu 2009) 5.

39 Marek Wierzbowski (ed), Postępowanie administracyjne [Administrative proceedings] (Wolters Kluwer Polska 2005) 244.

40 Barbara Adamiak, Janusz Borkowski, Kodeks postępowania administracyjnego. Komentarz [Code of Administrative Procedure. Commentary] (C.H. Beck 2009) 668.
} 
and individual proposals and complaints (J.P. Tarno ${ }^{41}$, W. Sokolewicz ${ }^{42}$, J. Lipski $^{43}$, W. Orłowski ${ }^{44}$ ). The new act of 11 July 2014 on petitions was supposed to "specify and determine the right to petition", whereas it neither defines the right to petition in a clear and explicit way nor does it distinguish between petitions and complaints and proposals.

Phrases such as "collective life" and "values demanding a special protection on behalf of the common good" cause serious problems as to their interpretation. It will be necessary not only to give them their own, concrete content, but first of all to separate them from the public interest, in which complaints and proposals can also be lodged (see Art. 63 of the Constitution). According to Art. 241 of the Administrative Procedure Code, the subject of a proposal can be as well the matters defined in Art. 2 par. 3 of the Act on petitions, or the subject of a petition can be the matters appropriate for proposals. Most certainly "the value demanding a special protection on behalf of common good" is the rule of law - both its reinforcement (Art. 241 of the Administrative Procedure Code) and the fight against its violation (Art. 227 of the Administrative Procedure Code).

One should also critically respond to a criterion of "common life" emphasized by the legislator. Vague phrases do not enable the distinguishing of petitions from complaints and proposals in an inevitable and indisputable way, so it will depend on the authority approval as to whether an individual's demand (e.g. related to the improvement of public transport) will be classified as a proposal ("better meeting of people's needs"), or as a petition ("the matters concerning collective life"). Phrases contained in the analysed rule are vague, inaccurate and ambiguous, which not only prevents the person entitled to petition from understanding the rule and the assessment of chance of its positive settlement, but it also combines with the risk of discrepancy and the faulty practice of law. ${ }^{45}$

The analysis of the act on petitions allows drawing a conclusion that accepted solutions lack clarity and precision. The main critical argument is that the act does not define the term of petition in an explicit and unambiguous way. Ipso facto it does not eliminate any doubts related to the mutual relations between petitions and complaints and proposals.

\footnotetext{
${ }^{41}$ Wojciech Chróścielewski, Jan Paweł Tarno, Postępowanie administracyjne i postępowanie przed sadami administracyjnymi [Administrative proceedings and proceedings before administrative courts] (Wolters Kluwer Polska 2011) 271.

${ }^{42}$ See Wojciech Sokolewicz, 'Komentarz do art. 63 Konstytucji' [Commentary to art. 63 of the Constitution] in Garlicki (n 32) 4.

${ }^{43}$ Jan Lipski, 'Prawo do petycji, skarg i wniosków w polskim systemie prawnym' [The Right to petitions, complaints and proposals in the Polish legal system] (2004) 4 Zeszyty Prawnicze BSE 119.

${ }^{44}$ Wojciech Orłowski, 'Prawo składania petycji, wniosków i skarg' [The right to file petitions, proposals and complaints] in Marek Chmaj, Wojciech Orłowski, Wiesław Skrzydło, Zbigniew Witkowski, Andrzej Wróbel, Wolności i prawa polityczne [Political freedoms and rights] (Zakamycze 2002) 159.

${ }^{45}$ Wójcicka (n 24) 27- 28.
} 


\section{Conclusions: Proposals to modify the Right to Petition}

The present shape of the right to petition is not final and it should not be. It needs certain reforms to adjust it to the standards and requirements of the modern country. The Polish legislator did not regulate clearly the right to petition. Especially the separation of proposals and complaints - beside petitions - deserves a critical approach.

The present regulation of the right to petition brings about numerous failures in the delineation of a demarcation line between these means. According to the legislator, a border between petitions and complaints and proposals was supposed to be marked out on the basis of a criterion of a number of entitled subjects. Petitions, unlike individual complaints and proposals, were treated as a kind of collective manifestations. The opinion of the members of the Committee on Constitutional Affairs of the National Assembly on the collective character of petition has not been reflected expressis verbis in the text of adopted constitution, and the legislator has made an attempt to distinguish the petitions from complaints and proposals on the basis of a subjective criterion. The definition suggested in the Act of 11 July 2014 on petitions does not remove any ambiguities as to its content. On the contrary, it creates new problems connected with crossing and overlapping the subject of petitions with the subject of complaints and proposals.

In my opinion, the right to petition is a public subjective law which constitutionally grants certain entities the power to present complaints and proposals and which lays a duty of receiving, considering, answering and the non-using of negative consequences towards their authors. The notion of petition itself should be treated as superior to complaints and proposals. Petition is not a separate device, but it is a manifestation which - depending on the subject - can have the character of a complaint or a proposal. The correlation of this right is an addressee's duty to accept and consider a petition as well as to give an answer and not to apply any negative consequences against a petitioner.

The consequence of accepting such a definition is the proposal of a new version of article 63 of the Constitution of the Republic of Poland, which should read as follows: "Everyone, individually or collectively, is entitled to submit a petition to the organs of public government and other entities in connection with the performance of their prescribed duties within the field of public administration, which are obliged to accept the petition and respond to it within time and under the conditions laid down by law".

In my opinion, a circle of a petition's addressees should be widened. Apart from organizations and social institutions, also other entities performing duties within public administration should be included. Moreover, the lack of a clear formulation of duty to receive and answer the petitions weakens the legal value of this institution.

It is also necessary to create an effective system of control and supervision over accepting, considering and dealing with petitions so that the right will not be illusory. Both part VIII of the Code of Administrative Procedure and the Act of 11 July 2014 on petitions accepted the model of proceedings on one administrative level. Dealing with a petition (a complaint, a proposal) takes the form of a notification with no means of appeal. Practice 
proves that the lack of effective legal measures leads to a slow, arbitrary and unreliable functioning of bodies in this respect, which makes this institution imperfect and often illusory. It is necessary to create a system of protection of the right to petition, so that this institution could really perform its functions. ${ }^{46}$ It is also desirable to give to administrative courts more powers to deal with complaints about the inactivity of a body and lengthy proceedings, as well as in a case when inadmissibility (refusal) of a petition is indicated and when a notification as to how the petition will be dealt lacks some constituent elements, crucial for its correctness.

\section{Bibliography}

Adamiak B, Borkowski J, Kodeks postępowania administracyjnego. Komentarz [Code of Administrative Procedure. Commentary] (C.H. Beck 2009).

Bodenhamer DJ, Our Rights, (Oxford University Press 2007).

Banaszak B, 'Opinia na temat projektu ustawy o petycjach' [Opinion on the draft Act about the petitions] in Opinie prawne na temat projektu ustawy o petycjach [Legal Opinions on the draft Act about the Petitions] (Kancelaria Senatu 2009).

Berlin I, Dwie koncepcje wolności [Two Concepts of Liberty] (Res Publica 1991).

Brückner A, Stownik etymologiczny języka polskiego [Etymological Dictionary of the Polish Language] (Wiedza Powszechna 1970) 403.

Chróścielewski W, Tarno JP, Postępowanie administracyjne i postepowanie przed sąami administracyjnymi [Administrative proceedings and proceedings before administrative courts] (Wolters Kluwer Polska 2011).

Chruściak R, Projekty konstytucji 1993-1997 [Drafts of the Constitutions 19931997] (Wydawnictwo Sejmowe 1997).

Corbett N, 'Parliamentary petitions: An untapped library resource [online]' (2011) 3 Australian Library Journal.

Działocha K, 'Prawo petycji w obowiązującym ustawodawstwie i proponowane kierunki zmian' [The Right to Petition in the existing legislation and the proposed directions of changes] in Prawo petycji w ustawodawstwie polskim [The right to petition in Polish legislation] (Kancelaria Senatu 2008).

Fox R, 'Engagement and participation: What the public want and how our politicians need to respond' (2009) 62 Parliamentary Affairs.

Garlicki L (ed), Konstytucja Rzeczypospolitej Polskiej. Komentarz [Constitution of the Republic of Poland. Commentary] (Wydawnictwo Sejmowe 2003).

Hauken T, Petition and Response. An Epigraphic Study of Petitions to Roman Emperors 181-249 (The Norwegian Institute at Athens 1998).

Kümin B, Würgler A, 'Petitions, Gravamina and the Early Modern State: Local Influence on Central Legislation in England and Germany' (1997) 17 Parliaments, Estates \& Representation.

Lang J, Wnioski obywatelskie w administracji państwowej [Citizens' proposals in the state administration] (Wydawnictwa UW 1976).

Lawson G, Seidman G, 'Downsizing the Right to Petition' (1999) 3 Northwestern University Law Review.

Lipski J, 'Prawo do petycji, skarg i wniosków w polskim systemie prawnym' [The Right to petitions, complaints and proposals in the Polish legal system] (2004) 4 Zeszyty Prawnicze BSE.

\footnotetext{
${ }^{46}$ It should be noted that the assessment of the admissibility of a petition must be subject to judicial review on the ground that a decision that a petition is inadmissible or that no further action is to be taken on it is liable to affect the essence of the right of petition and therefore constitutes a decision which may be the subject of an action for annulment in accordance with Article 263 TFEU. Judgment in Tegebauer v Parliament, EU:T:2011:466, paragraph 21.
} 
Płaza S, Sucheni-Grabowska A, 'Z badań nad polskim parlamentaryzmem XVI w.' [From the Research on Polish Parliamentarianism in the 16th century] (1974) 1 Czasopismo Prawno-Historyczne.

Riehm U, Böhle K, Lindner R, Electronic petitioning and the modernization of petitioning systems in Europe (Büro für Technikfolgen-Abschätzung beim Deutschen Bundestag 2014).

Sadurski W, Rights Before Courts: A Study of Constitutional Courts in Postcommunist States of Central and Eastern Europe (Springer 2014).

Smith NB, "'Shall Make No Law Abridging ...": An Analysis of the Neglected, But Nearly Absolute, Right of Petition' (1986) 54 University of Cincinnati Law Review.

Sucheni-Grabowska A, 'Kilka uwag o miejscu króla w sejmach ,złotego wieku”, [A Few Remarks on the Place of the King in the Seym in the "Golden Age"] in Krystian Matwijowski, Zbigniew Wójcik (eds), Studia z dziejów Rzeczypospolitej Szlacheckiej [Studies from the History of the Republic of the Nobility] (Wydawnictwo Uniwersytetu Wrocławskiego 1988).

Orłowski W, 'Prawo składania petycji, wniosków i skarg' [The right to file petitions, proposals and complaints] in Marek Chmaj, Wojciech Orłowski, Wiesław Skrzydło, Zbigniew Witkowski, Andrzej Wróbel, Wolności i prawa polityczne [Political freedoms and rights] (Zakamycze 2002).

Wojciech Uruszczak, 'Sejm w latach 1506-1540' [The Seym over the period 15061540] in Jerzy Michalski (ed), Historia sejmu polskiego, t. 1, Do schyłku szlacheckiej Rzeczypospolitej [History of the Polish Seym, vol. 1: Toward the end of the Noble Republic of Poland] (Państwowe Wydawnictwo Naukowe 1984).

Wierzbowski M (ed), Postępowanie administracyjne [Administrative proceedings] (Wolters Kluwer Polska 2005).

Winczorek P, Komentarz do Konstytucji Rzeczypospolitej Polskiej z dnia 2 kwietnia $1997 r$. [Commentary to the Constitution of the Republic of Poland of 2 April 1997] (K.E. Liber 2000).

Wójcicka E, 'Petycja w prawie konstytucyjnym państw współczesnych' [Petition in the Constitutional Law of Modern States] (2008) 1 Ius Novum.

Wójcicka E (translated by M. Bąk), 'Prawo petycji do Parlamentu Wielkiej Brytanii. Geneza i rozwój' [The Right to Petition the Parliament of Great Britain: Genesis and Development] (2010) 4 Studia Erasmiana Wratislaviensia.

Wójcicka E, Prawo petycji w Rzeczypospolitej Polskiej [The Right of Petition in the Republic of Poland] (Wydawnictwo Sejmowe 2015).

Zaeske S, Signatures of Citizenship: Petitioning, Antislavery, and Women's Political Identity (Chapel Hill 2003).

Zaret D, Origins of Democratic Culture: Printing, Petitions and the Public Sphere in Early Modern England (Princeton University Press 2000).

Zaret D, 'Petitions and the 'Invention' of Public Opinion in the English Revolution' (1996) 6 American Journal of Sociology.

Zięba-Załucka H, 'Prawo petycji w Rzeczypospolitej Polskiej' [The Right to Petition in the Republic of Poland] (2010) 4 Przegląd Prawa Konstytucyjnego. 